\title{
The Model of Development Policy Implementation of Village Owned Enterprises In Indonesia
}

\author{
Bambang Sudaryana \\ Polytechnic of Institutions and Professional Development Indonesia \\ (LP3I) Bandung, West Java Indonesia \\ sudaryana.b@gmail.com
}

\begin{abstract}
The low productivity of services in the village has been more due to the weakness of human resources in the field of management, organizations are less professional, the mastery of technology and marketing is weak, and the low quality of the entrepreneurship of the micro business. Problems developing village-owned enterprises also became more complicated because most micro businesses less facilitated by access to capital, information, market, technology and the factors supporting other businesses. Therefore, it is required in the form of affirmative action policies or affirmative action, namely that the government and local governments must develop this village-owned enterprises. The purpose of this study is to investigate the implementation of the policy on the management of villageowned enterprises, human resource managers, and the participation of private sector and government in the capital and mentoring as well as how much benefit to the welfare of rural communities. The method used in this study is descriptive quantitative method, the sampling technique using stratified random sampling and the number of population in this study amounted to 150 people. The conclusion from this study that the implementation of management policies village-owned enterprises, private sector and government participation in the capital as well as assistance and significant effect on the performance village-owned enterprises in order to improve the welfare of rural communities.
\end{abstract}

Keyword: Policy, Business, Village, welfare

\section{INTRODUCTION}

Village-owned enterprises (BUMDes is Badan Usaha Milik Desa) to be one answer from Article 33 of the 1945 Constitution "BUMDes are the pillars of the welfare of the nation, because BUMDes none other than the business that was founded on a shared commitment to the community, grassroots and that the village community, to cooperate together, worked together, and join forces to realize the people's economic welfare and prosperity of rural communities. Ministerial Regulation No.4 / 2015, village set out clear and detailed about the management of the technical implementation of village-owned enterprises (BUMDes) along with the roles and functions of each device BUMDes. village is generally accepted, that is still in the implementation in the area should be no adjustments are then governed by the Rules of the
Regent / Mayor in accordance with the state of nature, the environment and local culture. These regulations provide guidance to regions and villages in the establishment and management of BUMDes.

The provisions on village-owned enterprises in Act No. 6 of 2014 stipulated in Chapter X, with 4 chapters, namely Article 87 through Article 90 in Chapter $\mathrm{X}$ of the Act The village is mentioned that the village can establish village-owned enterprises called BUM the village is managed with a spirit of brotherhood and mutual cooperation. Businesses that can be run BUMDes is the effort in the economic and / or public service in accordance with the provisions of the legislation. Establishment BUMDes Consultation agreed and defined by Regulation village. BUMDes was designed with the advanced role of the village authorities and communities in greater proportion. When you reflect on the role of village 
government in the implementation of community development programs over the years, then through the model BUMDes is expected revitalization of the village government's role in the economic development of local / community development. Technically BUMDes there are still referring to the Minister Regulation No. 39 Year 2010 on village-owned enterprises. With the presence of Act No. 6 of 2014 and Government Regulation No. 43 Year 2014 About the Implementing Regulations of Law No. 6 of 2014 About the village, the next village gets a greater opportunity to increase its role in economic development of rural communities. In this case BUMDes $\mathrm{v}$ can be optimized instruments and its role as a local economic institutions that are legal at the village level to improve social welfare and rural incomes.

Currently BUMDes given the opportunity to develop various types of businesses according with the needs and potential of the village. As for the types of business include: 1) services 2) the distribution of nine basic commodities, 3) trade in agricultural products; 4) a small industry and households. As an institution which is also required to get a profit, of course, there is a mechanism that should be adhered to by the manager BUMDes in cooperation with other parties. The activities of a cross country necessary coordination and cooperation between the village government in the utilization of economic resources. In conducting cooperation with Third Parties by the business must go through consultation and approval of the Board of Commissioners BUMDes. In the daily activities of managers should refer to a system of rules that have been agreed as has been stated in the BUMDes regulation, and according to the principles of governance BUMDes.

There are some problems that arise related to the improved status of institutional legality BUMDes of Village Regulation into the legality of the notary deed; The first: BUMDes no overarching legal basis of the existence of BUMDes in the village. Although the actual implied passion for instituting BUMDes has been commissioned and is pedestrianized with the issuance of Law No. 8 of 2005 concerning amendments to the Law No.
32 of 2004 is now changed again to Law No. 23 Year 2014 on Regional Government, as mandated under Chapter VII in the fifth section that states the village government can establish village-owned enterprises in accordance with the needs and potential of the village with the hope to increase income and rural communities. As a follow up of the implementation of the establishment BUMDes, then pursuant to Article 78 Regulation 72 of 2005 regarding the village, explained that the regency / municipal government needs to establish Regional Regulation About the village-owned enterprises (BUMDes). But in reality the good intentions of the mandate of the Act and the Government Regulation has not been welcomed by the Government of Regency / City by indications that the absence of legislation governing the implementation of the process of improving the legality BUMDes thus be hampered in the legitimacy BUMDes law itself. Second; the legality of the establishment is also a big problem for the Financial Management Unit as embryonic BUMDes, because Financial Management Unit is business activities engaged in the Business Savings and Loans. In any country the business issues related to finance, monetary certainly set up in a relatively controlled manner even stricter compare other businesses. Meanwhile, the umbrella law on the implementation of business related to raise funds and distribute funds (savings and loans) in legitimacy based on Law No. 7 of 1992 on Banking and Law 25 of 1992 On Cooperatives were reinforced by Government Regulation No. 5 of 1995 on the Implementation of the Business Savings and Loans Cooperative. Based on this it can be concluded that the business entities that can legally carry out activities to collect funds and distribute funds or venture Savings and Loans only banking institutions and cooperatives. Therefore when BUMDes conducting Business Savings and Loans then this will happen so that the existence of a business venture illegality BUMDes course will meet the steep road ahead as more critical attitudes. Therefore, the government would need to immediately accommodate the legality of BUMDes through Act remember BUMDes very important role in rural areas.

Meanwhile, when BUMDes experienced problems in the process of legally legitimation 
positively by notarial deed on the grounds there is no clear legal of the implementation arrangements BUMDes it will bring another alternative in the form of institutional and electoral effort. The selection of institutional and business BUMDes must observe the basic objectives than the Government Programme, namely the nature of the Government Program by the presence Finance Manager Units as embryonic BUMDes is an asset to the village or in other words BUMDes are the property of the village that hopes can be made a tool for the welfare of society and the rural economy through increased revenue

In connection with the decentralization policy, strategy development BUMDes not solely based on the aspects of economic growth targets, but more important is to create economic activity that is conducive at the village level at least break the constraints of the development of rural enterprises in order to encourage the improvement of people's income so as to realize the welfare of society large. Commitment to empowering BUMDes should also pay attention to the organization of coaching governmental authority. The cooperation relations between the business community and local government need to be set and maintained in order to be in synergy. Therefore, it is necessary to conduct a study Model BUMDes as an agent of regional development and the promotion of the creation of the corporate sector in the countryside but with the cost of production and management is not too high and in order to drive the dynamics of the rural economy and as companies villages professionally managed and self referring to a system of rules that have been set out in the BUMDes regulation.

Other Research of Existence Corporation Effort Possession Village to Strong Village Condition Economic (Study in Landungsari Village, Dau Subdistrict, Malang Regency). This institution is one of organization have basic in level social and economic so as giver service for society especially about trade. Orientation of this organization in Landungsari Village is Region Role Malang Regency Number 20/2006 about Corporation Effort Possession Village. Method of the research in the research is qualitative research with descriptive. Focus the research is 1 . existence corporation effort possession village 2 . contribution existence corporation effort possession 3. support factor and obstruction factor as stronger economic village. The result of the research is existence corporation effort possession village done appropriate with region role Malang Regency then arranged by village with role village about corporation effort possession village. But, yet the existences not helping income donation village. Until can call the existence from the organization is just (Coristya Berlian Ramadana, Heru Ribawanto, and Suwondo. Consentration of Public Administration, Brawijaya University, Malang 2016;email: berlirama@gmail.com

\section{METHODOLOGY}

The research location is determined intentionally (purposive) in West Bandung District. The choice of location is based on the consideration that West Bandung District can represent the Village Owned Enterprise. The population in this study were The Management of Village Owned Enterprise . Number of samples / respondents drawn as many as 50 people. This amount is deemed to have met as expressed Singarimbun and Effendi (1995) that the sample with more than 30 have been included in a large sample.

The data used in this research is quantitative data and qualitative data obtained from both primary and secondary sources. The primary data obtained by observation, questionnaires, and interviews. While secondary data obtained from the village office, district offices, and other related institutions

$n=-1$
$n(d 2)+1$

The instrumentby using theformulaPearson ProductMoment Correlation(Pearson Product MomentCorrelation).asfollows:

$$
r_{x y}=\frac{N \sum x y-\left(\sum x\right)\left(\sum y\right)}{\left.\sqrt{\left\{N \sum x^{2}-\left(\sum x\right)^{2}\right\}\left\{N \sum y^{2}\right.}-\left(\sum y\right)^{2}\right\}}
$$

Structural equation modelto be testedtake the form of $\mathrm{Y}=\rho \mathrm{y} x_{1} \mathrm{X}_{1}+\rho \mathrm{y} x_{2} \mathrm{X}_{2}+\rho y \varepsilon$. And The Multiple 
Linear Regression Analysisasfollows: $\mathrm{Y}=$ $a+b_{1} X_{1}+b_{2} X_{2}+\varepsilon$.

\section{RESULT AND DISCUSSIONS}

A. Correlation between The Model of Development Policy Implementation $\left(X_{1}\right)$, the Village Owned Enterprises $\left(\mathrm{X}_{2}\right)$, with Improving Welfare ofthe Village (Y)
By using SPSS17 is known that the correlation coefficient multiple between variables The Model of Development Policy Implementation $\left(\mathrm{X}_{1}\right)$, the Village Owned Enterprises (X2), with Improving Welfare of The village $(\mathrm{Y})$ are shown in the table as follows

Table 1 Correlations

\begin{tabular}{|c|c|c|c|c|}
\hline & & Model & Enterprises & Performance \\
\hline \multirow[t]{3}{*}{$\begin{array}{l}\text { Kendall's Model } \\
\text { tau_b }\end{array}$} & $\begin{array}{l}\text { Correlation } \\
\text { Coefficient }\end{array}$ & 1.000 & $.617^{* *}$ & $.907^{* *}$ \\
\hline & Sig. (2-tailed) & & .000 & .000 \\
\hline & $\mathrm{N}$ & 70 & 70 & 70 \\
\hline \multirow[t]{3}{*}{ Enterprises } & $\begin{array}{l}\text { Correlation } \\
\text { Coefficient }\end{array}$ & $.617^{* *}$ & 1.000 & $.814^{* *}$ \\
\hline & Sig. (2-tailed) & .000 &. & .000 \\
\hline & $\mathrm{N}$ & 70 & 70 & 70 \\
\hline \multirow[t]{3}{*}{ Welfare } & $\begin{array}{l}\text { Correlation } \\
\text { Coefficient }\end{array}$ & $.907^{* *}$ & $.814^{* *}$ & 1.000 \\
\hline & Sig. (2-tailed) & .000 & .000 & \\
\hline & $\mathrm{N}$ & 70 & 70 & 70 \\
\hline
\end{tabular}

**. Correlation is significant at the 0.01 level (2-tailed).

Based on Table 1 the results of correlation Kendall's tau $b$ is known that variable of The Model of Development Policy Implementation $\left(\mathrm{X}_{1}\right)$, theVillage Owned Enterprises $\left(\mathrm{X}_{2}\right)$, withImprovingWelfareof The village (Y) 0.951, or by $95.10 \%$ and variable theVillage Owned Enterprises $\left(\mathrm{X}_{2}\right)$ also has close links with the variable Improving Welfare of the Village $(\mathrm{Y})$ of 0.874 or $87.40 \%$ and The Model of Development Policy Implementation $\left(\mathrm{X}_{1}\right)$ has a close relationship with the variable theVillage Owned Enterprises $\left(\mathrm{X}_{2}\right)$ of 0.814 or $81.40 \%$

Multiple correlation coefficient of The Model of Development Policy Implementation $\left(X_{1}\right)$, the Village Owned Enterprises $\left(\mathrm{X}_{2}\right)$, with Improving Welfare of The village (Y) 0.980 means that the relationship between is very closely. Value $\mathrm{R} 2=0$, 980 means that changes to Improving Welfare of the Village by $98.00 \%$ due to changes in The Model of Development Policy Implementation $\left(\mathrm{X}_{1}\right)$, and the Village Owned Enterprises $\left(\mathrm{X}_{2}\right)$.

\section{B. The Model of Development Policy Implementation( $\left.X_{1}\right)$ significant influence onImproving Welfare ofthe Village (Y)}

Based on thecorrelation datathat the influenceof variables The Policy Implementation $\left(\mathrm{X}_{1}\right)$ to Improving Welfare of the Village $(\mathrm{Y})$ which is calculated with a correlation coefficient of 0,980 or $\left(\operatorname{rx}_{1} \mathrm{y}\right)=0,980$.

Mean while, to declare the size of the contribution of variable $\mathrm{X}_{1}$ to $\mathrm{Y}$ variable or determinant coefficient $=r 2 X \quad 100 \%$ or $(0,980)$ ${ }^{2} \times 100 \%=96.04 \%$ while the remaining $3.96 \%$ is determined byother variables. Then to find 
significant levels of correlation coefficients $\mathrm{X}_{1}$ on $\mathrm{Y}$ with methods one side (one tailed) of output Measured probability) yields 0.00figure. Because the probability is much below 0.05, then the influence The Model of Development Policy Implementation of to improving Welfare of the Village is significant.
Table. 2. Model Summaryb

\begin{tabular}{|l|l|l|l|l|l|}
\hline Model & $R$ & R Square & $\begin{array}{l}\text { Adjusted } \\
\text { R Square }\end{array}$ & $\begin{array}{l}\text { Std. Error of } \\
\text { the Estimate }\end{array}$ & $\begin{array}{l}\text { Durbin- } \\
\text { Watson }\end{array}$ \\
\hline 1 & $980^{\mathrm{a}}$ & .978 & .977 & 1.44654 & .563 \\
\hline
\end{tabular}

a. Predictors: (Constant), Model , Enterprises

b. Dependent Variable: Welfare

Table 3. Coefficients ${ }^{a}$

\begin{tabular}{|c|c|c|c|c|c|c|c|}
\hline \multirow[b]{2}{*}{ Model } & \multicolumn{2}{|c|}{$\begin{array}{l}\text { Unstandardized } \\
\text { Coefficients }\end{array}$} & \multirow{2}{*}{$\begin{array}{l}\text { Standardized } \\
\text { Coefficients } \\
\text { Beta }\end{array}$} & \multirow[b]{2}{*}{$\mathrm{t}$} & \multirow[b]{2}{*}{ Sig. } & \multicolumn{2}{|c|}{ Collinearity Statistics } \\
\hline & B & Std. Error & & & & Tolerance & VIF \\
\hline 1 Constant) & 1297 & 1.496 & & .377 & .707 & & \\
\hline Model & .712 & 299 & .733 & 7.462 & .000 & .412 & 2.430 \\
\hline Enterprises & .281 & 572 & 682 & 7906 & .000 & .412 & 2.430 \\
\hline
\end{tabular}

a. Dependent Variable: Welfare

From the coefficient table illustrates that simple regression equation as follows:

$\hat{Y}=a+b_{2} X_{2}=12,97+0,680 X_{2}$

Constants of 16.44 states that there is no increase in the value of the variable the Village Owned Enterprises $\left(\mathrm{X}_{2}\right)$, then the value of Improving Welfare of the Village $(\mathrm{Y})$ is 12.97 . The regression coefficient of 0,682 states that any additions (for the sign+) of the scores or grades Quality of care would give rise to a score of 0,682 . T test to test the significance of constant and variable Y (Improving Welfare of the Village).

\section{Decision:}

Because the value of $t$ count $>t$ table, or $7,906>$ 1.671, then Ho is rejected seen in the column sig(significant) coefficient sig 0.000 or less than the probability value 0.05 or 0.05 value $>0,000$, then Ho is rejected and Ha accepted meaning that the regression coefficient is significant. Thus The Village Owned Enterprises significantly affect Improving Welfare of the Village.

Thus the regression equation is:

$\hat{Y}=a+b_{1} x_{1}+b_{2} X_{2}=12,97+0,980 X_{1}+0,682 X_{2}$
Constants of 16.44 states that if there is no increase in the value of the variable The Model of Development Policy Implementation $\left(\mathrm{X}_{1}\right)$ and The Village Owned Enterprises $\left(\mathrm{X}_{2}\right)$, then the value of Improving Welfare of the Village $(\mathrm{Y})$ is 12,97 . The regression coefficient of 0,980 and 0 , 682states.That any additions (for the sign+) of the scores or grades The Model of Development Policy Implementation and The Village Owned Enterprises will give rise to a score of 0,98 and 0 , 682

C. The Model of Development Policy Implementation $\left(X_{1}\right)$ and The Village Owned Enterprises $\left(X_{2}\right)$ together equally significant influence on Improving Welfare of the Village (Y)

F test in the ANOVA table to test the significance of the constants and The Model of Development Policy Implementation dependent variable (Improving Welfare of the Village). Test criteria regression coefficient of The Village Owned Enterprises and Improving Welfare of the Village is as follows: 
Table 4. ANOVA

\begin{tabular}{|l|l|l|l|l|l|}
\hline Model & Sum of Squares & df & $\begin{array}{l}\text { Mean } \\
\text { Square }\end{array}$ & F & Sig. \\
\hline 1 Regression & 6979.349 & 2 & 3489.675 & 1029.515 & .000 \\
Residual & 156.936 & 75 & 2.092 & & \\
Total & 7136.286 & 77 & & & \\
\hline
\end{tabular}

a. Predictors: (Constant), Enterprises, Model

b. Dependent Variable: Welfare

Decision :

It turned out that $\mathrm{F}$ count $>\mathrm{F}$ table, or $10,29>4.08$ then Ho is rejected and $\mathrm{Ha}$ accepted that The Model of Development Policy Implementation $\left(\mathrm{X}_{1}\right)$ and The Village Owned Enterprises $\left(\mathrm{X}_{2}\right)$ together equally significant influence on Improving Welfare of the Village(Y). It appears that at column Sig (a significant) in the table Anovab the Sig. 0,000 or smaller than the probability value 0.05 or 0.05 value $>0.000$, then Ho Development Policy Implementation is rejected and $\mathrm{Ha}$ accepted, meaning that multiple regression coefficient is significant. So The Model of Development Policy Implementation $\left(X_{1}\right)$ and The Village Owned Enterprises $\left(\mathrm{X}_{2}\right)$ together equally significant influence on Improving Welfare of the Village (Y)

\section{CONCLUSION}

And discussion of research findings indicate various conclusions relating to:

a. That there is a relationship / correlation is very strong / strong between The Model of Development Policy Implementation $\left(\mathrm{X}_{1}\right)$ and The Village Owned Enterprises $\left(\mathrm{X}_{2}\right)$ together with variable Improving Welfare of the Village (Y) of 0.980 or $98.90 \%$ and the remaining $1.10 \%$ are other factors that are not included in the research model (Epsilon).

b. That there is significant influence of variables The Model of Development Policy Implementation $\left(\mathrm{X}_{1}\right)$ to Improving Welfare of the Village $(\mathrm{Y})$ c. That there is significant influence of variables The Village Owned Enterprises $\left(\mathrm{X}_{2}\right)$ on Improving Welfare of the Village $(\mathrm{Y})$

d. That there is significant influence of variables The Model of Development Policy Implementation $\left(\mathrm{X}_{1}\right)$ and The Village Owned Enterprises $\left(X_{2}\right)$ together toward Improving Welfare of the Village $(\mathrm{Y})$

\section{SUGGESTIONS}

1. There shall be established an internal control unit of the mechanism for channeling and utilization of funds to BUMDes in BUMDes comes from grants provided by the government-owned village to village, and investors who want to give a loan,

2. The establishment in the village-owned enterprises is very much, needs to be focused kind business what is most appropriate for development

\section{ACKNOWLEDGEMENTS}

We are gratefully acknowledged to Local Government of West Bandung . Special thanks to the Regent of the respective Public Administration Institution, and all subjects who participated in the study are gratefully acknowledged. Conflict of interest declaration: There is no conflict of interest among the authors. Funding: This study received no specific grant from any funding agency. Authors' contributions Bambang Sudaryana, conception of study, data collection, analysis and interpretation of results, drafting of manuscript, review of manuscript and interpretation of results.

\section{REFERENCES}

Ahmad Sofyan (2015), Pendirian Dan Pengelolaan Badan Usaha Milik Desa

Coristya Berlian Ramadana, Heru Ribawanto, Suwondo Jurusan Administrasi Publik, Fakultas Ilmu Administrasi, Universitas Brawijaya Malang 
Keberadaan Badan Usaha Milik Desa (Bumdes) sebagai Penguatan Ekonomi Desa (Studi di Desa Landungsari, Kecamatan Dau, Kabupaten Malang)

Kemendagri (2011) Pentingnya Mendorong Pelaku Usaha Mikro Dalam Badan Usaha MilikDesa (BUMDes)

Mubyarto. (1984). Pembangunan Pedesaan. Yogyakarta, P3PK UGM. ]

Nurcholis, Hanif. (2011). Pertumbuhan dan Penyelenggaraan Pemeritahan Desa.Jakarta, Erlangga.

Peraturan Pemerintah Nomor 72 Tahun 2005 tentang Desa.Jakarta, Direktorat Jendral Otonomi Daerah.

Peraturan Desa Landungsari Nomor 02 Tahun 2008 tentang Pembentukan Badan Usaha Milik Desa. Malang, Kabupaten Malang.

Peraturan Daerah Kabupaten Malang Nomor 20 Tahun 2006 tentang Badan Usaha Milik Desa.Malang, Kabupaten Malang

Peraturan Menteri Dalam Negeri Nomor 39 Tahun 2010 tentang Badan Usaha Milik Desa (c.2).Jakarta, Menteri Dalam Negeri.

Sulistyani, AT. (2004). Kemitraan dan ModelModel Pemberdayaan. Yogyakarta, Gava Media.

Soemarmo. (2005). Analaisis Pelaksanaan Pendekatan Partisipatif pada Proses Perencanaan Pembangunan di Kota Semarang.Semarang, Universitas Diponegoro.

Undang - Undang Nomor 32 Tahun 2004 tentang Pemerintah Daerah. Jakarta, Direktoral Jenderal Otonomi Daerah.

Widjaja, HAW. (2002). Pemerintahan Desa/Marga Berdasarkan Undang-Undang Nomor 22 Tahun 1999 tentang Pemeritahann Daerah.Jakarta, PT.Raja Grafindo Persada.
Widjaja, HAW. (2002). Otonomi Daerah dan Daerah Otonom.Jakarta, PT. Raja Grafindo Persada. 